\title{
Harvesting of Non-timber Forest Products by the Local Communities in Mount Halimun-Salak National Park, West Java, Indonesia
}

\author{
Yelin Adalina $^{1^{*}}$, Dodik Ridho Nurrochmat ${ }^{2}$, Dudung Darusman ${ }^{2}$, Leti Sundawati ${ }^{2}$ \\ ${ }^{1}$ The Center for Research and Development on Forest Conservation and Rehabilitation \\ Jl Gunung Batu No. 5, PO Box 165, Bogor, Indonesia 16610 \\ ${ }^{2}$ Department of Forest Management, Faculty of Forestry, Bogor Agricultural University, \\ Academic Ring Road, Campus IPB Dramaga, PO Box 168, Bogor, Indonesia 16680
}

\section{Received April 2, 2014/Accepted August 22, 2014}

\begin{abstract}
Local communities around the forest need to be involved in securing the sustainability of Mount Halimun Salak National Park (MHSNP), for example through the utilization of non-timber forest products (NTFPS) such as flora in the utilization zone. This research was aimed to provide data and information about 3 kinds of vegetation producing resin (Pinus merkusii, Agathis dammara, and Hevea brasiliensis) and the harvesting NTFPs by the community in the forest vicinity. The research was conducted in MHSNP, and data were analyzed through quantitative-descriptive. The survey method was employed in the study through interviews of respondents using structured questionnaires. This study revealed that the vegetations at the stage of tree comprised of the following: (1) Agathis dammara (damar) with Importance Value Index (IVI) of 276.15\% and density of 452 trees ha ${ }^{-1}$, (2) Pinus merkusii (pine) trees with IVI of $300.0 \%$ and density of 552 trees $h^{-1}$, and (3) Hevea brasiliensis (rubber) trees with IVI of $217.42 \%$ and density of 85 trees $h a^{-1}$. Pine, damar, and rubber sap tapping afforded contribution in 59.18, 4.41, and 60.71\%, respectively of the total household incomes. Community involvement in the collection of NTFPs in national parks implicated to the increasing of the forest communities revenue and the forests will be maintained since public can get benefits from forest resources. Forest management should be directed as a producer of NTFPs that can increase the economic income of forest communities with attention to ecological factors.
\end{abstract}
Keywords: Harvesting, non-wood forest products, Mount Halimun-Salak National Park, community around the forests

*Correspondenceauthor,email:yelinadalina@yahoo.com,tel.:+62-817852242

\section{Introduction}

In the year 2003, Mount Halimun-National Park (MHNP) area was expanded from 40,000-113,357 ha in accordance with the decree issued by the Indonesia's Ministry of Forestry Number $175 / \mathrm{Kpts}-\mathrm{II} / 2003$ as one entity called Mount Halimun-Salak National Park (MHSNP). With the release of the decree the function of the forest has changed from production function which was formerly managed by the state-owned forest enterprise Perum Perhutani to conservation area of pine (Pinus merkusii Jungh. et de Vriese) and damar (Agathis dammara). The pine and damar species is an exotic plant in the national park (Sunaryo et al. 2012). Exotic plants can be a major threat to native plant species (van Wilgen \& Richardson 2012).

Philosophically, an area designated as a national park has 3 benefits, namely the ecological, economic, and social benefits. Although in the philosophical concept, the national park is used as much as possible to improve the welfare of the communities, even though in operational practice, it is not easily realized. The consequences of national park expansion is the loss of public access rights to work on farmland that has been long done (Rahmawati et al. 2008).
The expansion of the area of MHSNP has caused various problems such as encroachment and degradation of natural resources (JICA 2007), land ownership conflict, and over use of natural resources (Yatap 2008). Although the national park utilization concept is to improve the welfare of the communities, in operational practice it was not easy to be realized (Dunggio \& Gunawan 2009). These problems are often correlated with the low level of welfare of the people around the national park (Dunggio \& Gunawan 2009). In 2006 , the number of poor households in and around the region MHSNP was 68,113 households (JICA 2007).

MHSNP existence cannot be separated from the people residing in and around the area. Junaedi and Maryani (2013) argued that the management of forest resources needs to be done with the whole ecosystem oriented. Forest conservation cannot be separated from the surrounding environment, both ecological, economical, and social. Good forest management should provide optimal benefits to the society, the forest manangement and the surrounding stakeholders (Birgantoro \& Nurrochmat 2007). The community and the forest ecosystem are interdependent, so that it will keep the existence and preservation of forests if it can gain direct and 
indirect benefits from the resource (Darusman 2000).

In managing the national park, one of the forest resources that has a comparative advantage with the forest communities are the non-timber forest products (NTFPs). The NTFPs can contribute significantly to their livelihoods of forest dependent communities. Harvesting the NTFPs has become an economically acceptable ecological option of development (Ahenkan \& Boon 2011). Therefore, the harvesting of NTFPs by forest communities should be pursued. NTFPs have benefits for the conservation of forest resources and to increase the income of local communities. This research was conducted in order to determine the vegetation of pine, damar and rubber trees as well as assess the harvesting of NTFPs by the community in the national park area.

\section{Methods}

The research was conducted during October-December 2012 in 3 villages which are directly adjacent to the MHSNP, namely (1) Cipeuteuy Village, Subdistrict Kabandungan, Sukabumi Regency, (2) Tamansari Village, Taman Sari Subdistrict, Bogor Regency, and (3) Pangradin Village, Jasinga Subdistrict, Bogor Regency. The criteria for the site selection was based on the program of NTFP sap pine and damar collection. The research was using quantitative and qualitative approach. Survey was done using interviews with respondents through the use of structured questionnaires. Selection of respondents was done using purposive sampling, with the rubber sap, pine resin, and gum resin NTFPs collectors community in the MHSNP area. The total number of respondents was 63 that consist of 24 gum resin collectors, 28 rubber sap collectors, and 11 pine sap collectors.

The measurement of NTFP to estimate the availability of NTFP for current and future harvests took place in 3 research locations where 3 exudates-producing tree species have already been utilized by the community. The species comprised in an area of 15 ha of damar trees, 5 ha of pine trees, and 75 ha of rubber (Hevea brasiliensis) trees. Vegetation analysis on each level of the tree growth was performed using the checkered path measuring $20 \times 20 \mathrm{~m}^{2}$ for trees, $10 \times 10 \mathrm{~m}^{2}$ for poles, $5 \times 5 \mathrm{~m}^{2}$ for saplings, and $2 \times 2 \mathrm{~m}^{2}$ for seedlings of each species plantation area. Vegetation analysis was conducted on 12 plots in each vegetation type.

The types of data collected consist of primary and secondary data. Primary data is data regarding NTFP collection that utilized by the community: types of NTFPs, the number of shots, the selling price, frequency of collection, income, and the conditions of the vegetation types of pine, damar and rubber plants. Secondary data is data regarding the biophysical condition of research sites. Data were analyzed descriptively. The data was to determine the importance of value index (IVI) through the analysis of dominance, frequency, and density using equation found in (Soerianegara \& Indrawan 2002). IVI is a quantity that can describe a type of dominance against other strains in a stand (Soerianegara \& Indrawan 2002). The higher value of IVI of species means the greater dominance of the species growth. The equations are used as shown in Equation [1] until Equation [6] (Soerianegara \& Indrawan 2002).

$$
\begin{aligned}
& \text { Density (K) } \\
& =\sum \text { individuals/area of sampling } \\
& \text { plot } \\
& =(\mathrm{KJ} / \mathrm{KT}) \times 100 \% \\
& \text { Dominance (D) } \\
& =\text { basal area of a species/area of } \\
& \text { sampling plot } \\
& =\sum \mathrm{PJ} / \sum \mathrm{PT}
\end{aligned}
$$

The IVI for pole stage and mature-tree stage is the sum of the relative density (RD), relative dominance (DR), and the relative frequency (RF) as shown in Equation [7] (Soerianegara \& Indrawan 2002).

$\mathrm{IVI}=\mathrm{RD}+\mathrm{DR}+\mathrm{RF}$

The IVI for seedling stage is the sum of the relative density (RD) and relative frequencies (RF) as shown in Equation [8] (Soerianegara \& Indrawan 2002). Furthermore, this IVI used as the basis for determining the level of dominance of a particular type of tree.

$\mathrm{IVI}=\mathrm{RD}+\mathrm{RF}$

Diversity of vegetation identified by using Shannon Diversity Index (Soegianto 1994). The equations is as shown in Equation [9]:

$H^{\prime}=\sum p i \log p i$, where $p i=n i / N$

note: $P i$ is the ratio between the number of individuals of all species by the total number of individuals.

\section{Results and Discussion}

MHSNP is located in West Java Province, Indonesia, has an area of $\pm 113,357 \mathrm{ha}$, and has a height ranging from $500-2,211 \mathrm{~m}$ asl. The average of rainfall ranges from 4,000-6,000 mm year ${ }^{-1}$, according to Schmidt and Ferguson (1951) means climate type B. The average air temperature of $31.5^{\circ} \mathrm{C}$ with average of relative humidity is $88 \%$. MHSNP land cover in the region are composed of natural forests, plantations, mixed farms, rubber plantations, tea gardens, shrubs, grass, paddies fields, fields, and land up. Forest plantations in the MHSNP region previously existed as production forests area managed by Perum Perhutani (Figure 1).

Measurement of damar vegetation was conducted in Cipeuteuy Village located at an altitude of 750-800 m asl with a hilly topography. Based on climate classification by Schmidt and Ferguson (1951), the village was categoryzed as type B precipitation, with $2.600 \mathrm{~mm}$ rainfall per year, an average temperature of $18-32{ }^{\circ} \mathrm{C}$ and an average of relative 

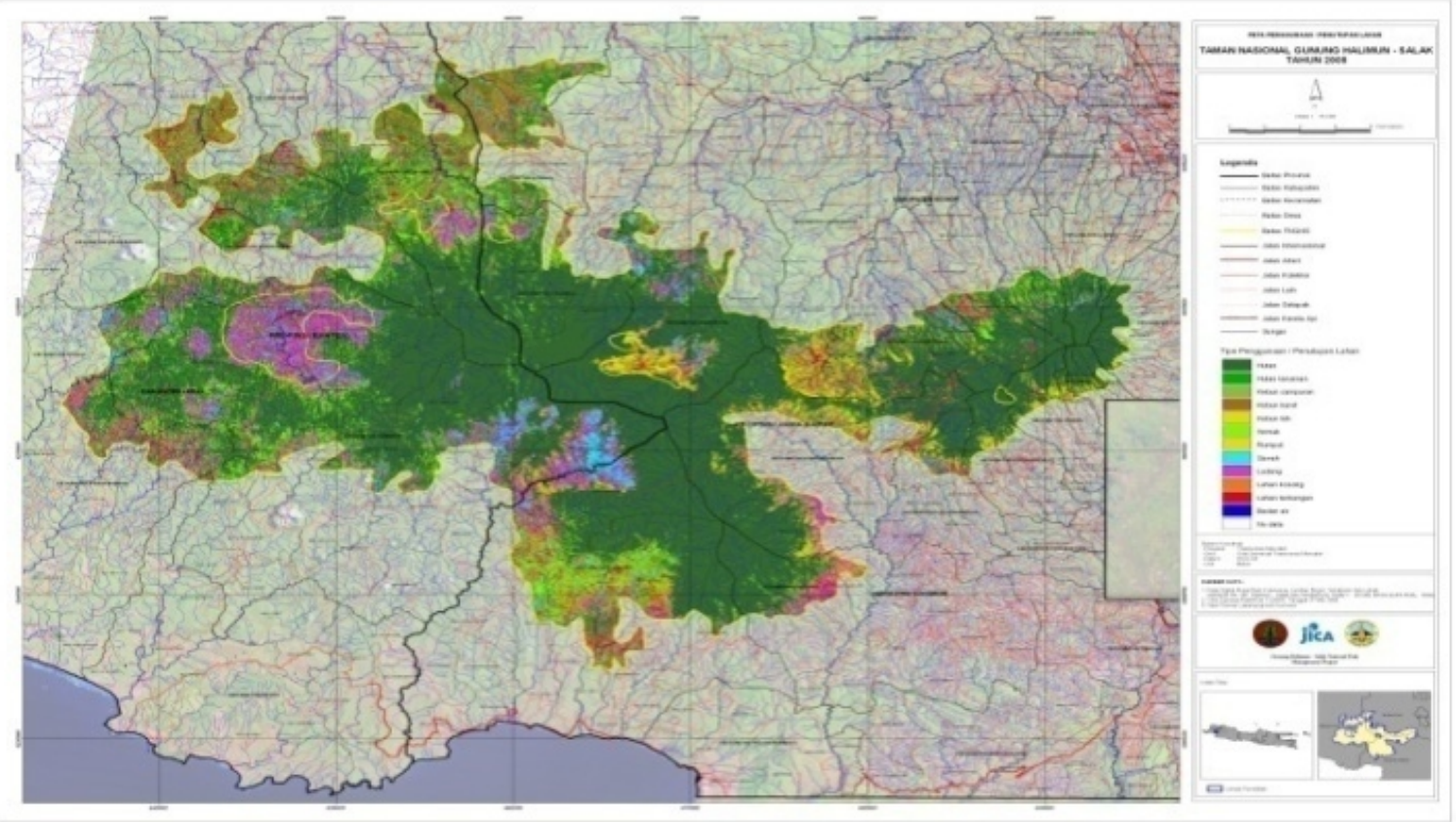

Figure 1 Mount Halimun Salak National Park area land cover map of 2005 (BTNGHS 2007).

humidity of $79 \%$. Most of the Cipeuteuy Village area was MHSNP forest, covering an area of 2,115 ha, or approximately $56.45 \%$ of the total area of 3,746 ha (Village of Cipeuteuy 2011).

Measurement of pine vegetation was done in Tamansari Village. Elevation in the study area was $740 \mathrm{~m}$ asl with an average temperature ranges between $25-28{ }^{\circ} \mathrm{C}$, and average of relative humidity ranges between $65-72 \%$. The climate in this region according to the classification of Schmidt and Ferguson (1951) categorized as type A, with average of annual rainfall is 2,600 mm year ${ }^{-1}$. Most of the Tamansari Village was MHSNP area, covering an area of $600 \mathrm{ha}$, or approximately $64.14 \%$ of the total area of the village (Village of Tamansari 2011).

Measurement of the rubber vegetation carried out in Pangradin Village located at an altitude of $250-600 \mathrm{~m}$ asl with undulating topography, hilly, and mountainous. The temperature ranges between $24-32{ }^{\circ} \mathrm{C}$, with average humidity of $80 \%$, and annual average of rainfall of $1500 \mathrm{~mm}$ year $^{-1}$. Forest area of MHSNP in Pangradin Village measuring 85 ha or $7.23 \%$ of the village area (Village of Pangradin 2011).

The harvesting of non-timber forest products at MHSNP area The harvesting of NTFPs in the MHSNP region by communities around the forest in this research consisted of the collection of damar, pine, and rubber sap. Jacobson and Shiba (2012) suggested that the development of NTFPs in the forest management should be planned to increase alternative communities income that have dependency on forest resources by considering socio-economic factors and forest conditions. Management of MHSNP has exerted efforts to optimize the function of the forest by utilizing the potential of existing programs through the collection of NTFPs. Collection programs of pine and damar sap in MHSNP region were socialized in June 2012. The program began in September 2012 under the momerandom of understanding (MoU) between the tapper farmers and MHSNP Hall which was collaborated in cooperation with Sukabumi Development Observer Foundation (SDOF) as a donor and the collector of sap tapping results. The MoU mentioned (1) farmers were obliged to sell the results of pine sap tapping and damar to SDOF with the price that's already agreed, which was IDR3,000 $\mathrm{kg}^{-1}$, (2) must follow the instructions and technical guidance provided by the officer, (3) tapping farmers as members of farmer groups village conservation society (VCS) and actively participated in regional security efforts MHSNP. If there are farmers who break the rules that have been agreed, then the MHSNP hall would revoke the license of NTFPs collection.

The harvesting of damar sap in the Cipeuteuy Village conducted by members of VCS of Sukagalih Kopel. Damar plants that existed in MHSNP region was originally a production forest managed by Perum Perhutani. These crops were grown by the communities since 1993. Proximity of housing to the damar plants area approximately $300 \mathrm{~m}$. Damar sap tapping was conducted together by members of VCS of Sukagalih Kopel. The number of VCS members involved in the program were 24 people. The production of damar sap in the first harvest was $150 \mathrm{~kg}$ and that in the second harvest was $50 \mathrm{~kg}$ of 1.500 trees tapped for 15 days tapping. The result of sap was sold to SDOF with the selling price of IDR3, $000 \mathrm{~kg}^{-1}$. The total income of VCS Kopel from damar sap was IDR600,000 month ${ }^{-1}$. The revenue of damar sap was then divided equally to all the members of VCS Kopel involved in the program, so that each member received IDR25,000 person ${ }^{-1}$ month $^{-1}$. The contribution of damar sap 
income in Cipeuteuy Village was very small to the total household income of farmers, which was amounting of $1.28 \%$ to $4.41 \%$ or $2.34 \%$ of the average income (Table 1 ). These results were different from the study conducted by Wijayanto (2002) which suggested that the damar sap contributed significantly to household income in about $65 \%$ of the household total income of the farmers in West Lampung Krui Coastal. Maryudi (2012) expressed that the average income of damar tapping farmers in the forest managed by Perum Perhutani was IDR1,000,000 month ${ }^{-1}$ tappers ${ }^{-1}$.

The low of damar sap result in Cipeuteuy Village was due to lack of understanding of farmers on tapping technique, the least number of tapping holes tree ${ }^{-1}$, and the high number of unproductive damar trees. Resin production per tree was strongly influenced by various factors, such as grown site quality, trees age, stand density, genetic traits, growing altitude above sea level, bark thickness, trunk diameter, topography, editorial quality and direction of tapping (Irawan et al. 2007). Collecting program of damar sap in Cipeutey Village was only implemented in one month because the farmers did not want to continue this program due to low production result and low selling price of sap. The farmers considered as laborers only in the tapping program, and they wanted the sale price to be adjusted with standard price of damar sap in the market. Based on Decree Number 22/2012, reference price for damar sap was IDR $8,500 \mathrm{~kg}^{-1}$.

Pine plants which exist in MHSNP region are original plants of production forest managed by Perum Perhutani. In the beginning of region expansion, community involvement in pine sap tapping was carried out under the Perhutani management through the community joint forest management (CJFM). Pine sap collection program in the MHSNP region is done to improve the welfare of forest communities by constantly ensuring the preservation of the ecosystem. The harvesting of pine sap in the Tamansari Village should be done by members of VCS consisting of 39 people, but in fact, the pine sap tapping is just conducted by 11 people, because some members of the VCS are not interested in collecting pine sap. They have other main works so they do not have the time in tapping activities. In addition, the price of sap received by farmers is still low. Cahyono (2011) state that the factors that influence farmers' willingness on tapping pine are the age of the farmer, location, and price on tapping sap.

The number of farmers managing pine trees varies depending on the ability of each farmer in tapping (Figure 3). The farmers can do the tapping of 30-60 trees day ${ }^{-1}$ person $^{-1}$ or 42 trees day ${ }^{-1}$ person ${ }^{-1}$ in the average. The distance of the location of the tapping from their homes is about 0.1 to $2 \mathrm{~km}$. The number of trees managed is 300 to 1,000 trees person $^{-1}$ or 451 trees $^{\text {person }}{ }^{-1}$ in the average. Sap harvesting is implemented every 15 days, with sap production of 160 to $450 \mathrm{~kg} \mathrm{month}^{-1}$ person $^{-1}$ or $285.45 \mathrm{~kg} \mathrm{person}^{-1} \mathrm{month}^{-1}$ in the average. The production average of a tree is $316 \mathrm{~g}$ (Figure 2, Table 1). Sukadaryati and Dulsalam (2013) state that the production of sap each tree varies depending on the internal factors of the pine tree it self that cause the tree to produce more sap than other trees.

Rubber in Indonesia was one of the crops plantation which had an important role as a source of foreign exchange earnings, employment, driving economic growth, preservation of the environment, and natural resources (Sannia et al. 2013). Rubber plants at the site MHSNP region had been planted by the villagers of Pangradin before the expansion of MHSNP region. The harvesting of rubbers in MHSNP region had been done by the society of Pangradin Villagers since long time, but had not yet formed $\mathrm{MoU}$ between the communities and MHSNP Hall in collecting of rubbers. Acreage managed by the farmers in the area of MHSNP ranges from $0.25-3.0$ ha. The majority of farmers in the Pangradin Village planted rubber in the arable land in MHSNP area. The rubber plant was a source of daily income of farm households become the main reason people choose this type of plant. The ability of farmers to conduct the tapping of 200-300 trees day ${ }^{-1}$ with production of sap obtained by $7-15 \mathrm{~kg}$ of latex per 2 days or of $11 \mathrm{~kg}$ in the average. Farmers sold processing rubber to collectors located around the village with a selling price of IDR5,000 kg-1. Rubber latex that was obtained then processed into rubber sit

Table 1 Production and income of farmers from damar plant, pine and rubber sap in the MHSNP area

\begin{tabular}{|c|c|c|c|}
\hline Plant type & $\begin{array}{l}\text { Agathis dammara } \\
\text { (Damar ) }\end{array}$ & $\begin{array}{l}\text { Pinus merkusii } \\
\quad \text { (Pine) }\end{array}$ & $\begin{array}{l}\text { Hevea brasiliensis } \\
\quad \text { (Rubber) }\end{array}$ \\
\hline Planted area & 15 & 5 & 75 \\
\hline Number of trees ha ${ }^{-1}$ & 452 & 662 & 745 \\
\hline Age of plants (year) & 20 & 25 & 10 \\
\hline Number of tappers (person) & 24 & 11 & 28 \\
\hline Sap price $\left(\mathrm{IDR} \times 1,000 \mathrm{~kg}^{-1}\right)$ & 3 & 3 & 5 \\
\hline Distance to the location of the tapping $(\mathrm{km})$ & 0.3 & 1.05 & 3.5 \\
\hline Number of plants that are managed person ${ }^{-1}$ & 63 & 451 & 682 \\
\hline Number of trees in tapping day ${ }^{-1}$ person $^{-1}$ & 9 & 42 & 250 \\
\hline Production sap tree ${ }^{-1}\left(\mathrm{~g}^{-1} 15\right.$ days $)$ & 100 & 316 & 125 \\
\hline Latex production $\left(\mathrm{kg}\right.$ month $^{-1}$ person $\left.^{-1}\right)$ & 8.34 & 285.45 & 167.77 \\
\hline Sap revenue $($ IDR $\times 1,000$ month person $)$ & 25 & 700 & 832 \\
\hline $\begin{array}{l}\text { Average total income of farmers from the main and side jobs } \\
\left(\text { IDR } \times 1,000 \text { month }^{-1} \text { farmer }^{-1}\right)\end{array}$ & 1176 & 1187 & 1439 \\
\hline
\end{tabular}




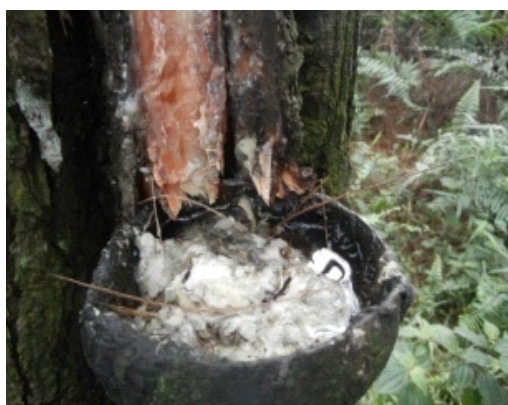

Figure 2 The inflicting of injury on tree-stem for exudates.

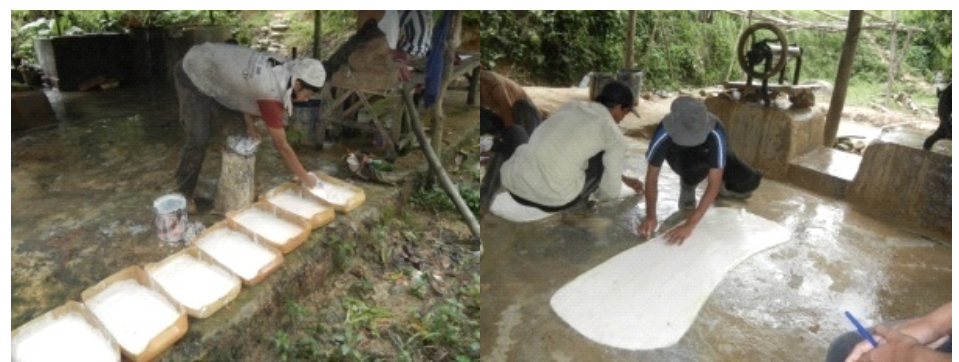

Figure 4 Collection of rubber by the community.

sheets ready for sale at a price of IDR $25,000 \mathrm{~kg}^{-1}$ (Figure 4, Figure 5, Figure 6). The average of rubber production was $105-300 \mathrm{~kg} \mathrm{month}^{-1}$ person $^{-1}$ or of $167.7 \mathrm{kgmonth}^{-1}$ person $^{-1}$ in the average (Table 1). The production size of the sap produced by farmers depended on the local area managed, tapping frequency, number of trees tapped, and the age of the plant. The average of latex production in Pangradin Village was $177 \mathrm{~kg} \mathrm{ha}^{-1}$ month $^{-1}$ by the number of trees 682 trees ha $^{-1}$. This value was lower than the study conducted by Wulansari et al. (2012), that was equal to $200 \mathrm{~kg} \mathrm{ha}^{-1} \mathrm{month}^{-1}$ by the number of trees of 500 trees $^{-1} \mathrm{a}^{-1}$ in District Hatungan Tapin Regency. The low production of rubber in Pangradin Village associated with land management and maintenance of the plants that were less than optimal. Rubber farming cultivated in the absence of proper maintenance such as fertilizing and weeding.

Farmers' income from rubber tapping in MHSNP were IDR525,000-1,500,000 month person $^{-1}$ or IDR832,000 month $^{-1}$ person $^{-1}$ in the average depend on acreage they managed. Latex made significant contributions to the household income in $22.32 \%$ to $100.00 \%$ or $60.71 \%$ in the average (Table 1). Rubber tapping results in the MHSNP area could increase the income of farmers' households in Pangradin Village. This was consistent with a research that was conducted by Wulansari et al. (2012) which suggested that the rubber commodity had contributed significantly to the economy of the community in Sintang Regency.

Vegetation of dammar, pine, and rubber trees at MHSNP area The IVI is a quantity that describes a type of dominance against other strains in a stand (Soerianegara \& Indrawan 2002). Based on the calculation of IVI, there were 2 subspecies of damar tree in the MHSNP forest area in the

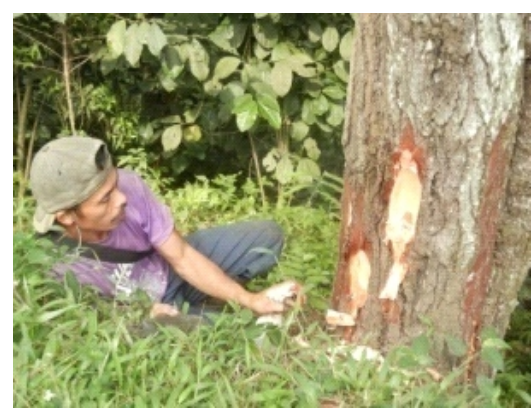

Figure 3 Exudate from pine trees.

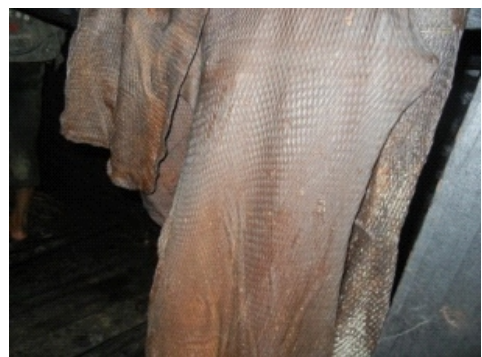

Figure 5 Rubber sit ready for sale.

Cipeuteuy Village, namely, damar with IVI of $276.2 \%$ and Artocarpus champedan with IVI of $23.9 \%$. In general, the $A$. champedan grow naturally. The pole level was dominated by damar with IVI of $272.8 \%$, density of 100 individuals ha $^{-1}$, and coffee (Coffea spp.) with IVI of $27.2 \%$ and density of 8.3 individuals $\mathrm{ha}^{-1}$. The dominant type of saplings level was the coffee plant with IVI of $200 \%$ (Table 2, Figure 7). The number of coffee saplings were lower than damar, because coffee beans were eaten by Paradoxurus hermaphroditus. The IVI of damar showed a downward trend from tree to pole phase, and the natural regeneration of damar was less good. This was indicated by the density of the damar which tend to decrease from tree phase to pole phase. Soerianegera and Indrawan (2002) suggested that the number and frequency of tree species regeneration can be used as a basis on predicting the composition and volume of the stands in the future.

The IVI calculation of pine forest in Tamansari Village indicated that the dominant plant for tree and pole level was pine with IVI of $300 \%$, however no dominant species of saplings (Table 2, Figure 8). It showed the condition of the vegetation in the study site was dominated by monoculture crop. Research result of Hastuti et al. (2011) showed that vegetation in National Park of Mount Merbabu, based on clustering ecosystem, tend to monoculture (pine) with IVI of $300 \%$.

The IVI on the tree level of rubber plantations in the Pangradin Village were rubber plants with IVI of $217.4 \%$ and pine with IVI of $82.6 \%$. The pole phase were dominated by the rubber with IVI of $258.7 \%$, density of 660 individu ha ${ }^{-1}$, which was followed by Durio zibethinus with IVI of $21.5 \%$, density of 20 individuals ha ${ }^{-1}$, and Garcinia mangostana with IVI of $19.9 \%$, density of 20 individuals $\mathrm{ha}^{-1}$. The sapling phase was dominated by rubber with IVI of $200 \%$, density of 
1,040 trees ha $^{-1}$ (Table 2, Figure 9). The high IVI of the 3 species indicated the species dominance in the growth place. The IVI of pine was higher than the other 2 types of plants. This indicated that the area was entirely dominated by pine plantation, as the higher IVI value of a species indicates the greater dominance of the species on growth place (Soerianegara \& Indrawan 2002). Vegetation density at tree level of damar by 452 trees ha ${ }^{-1}$, pine by 552 trees $\mathrm{ha}^{-1}$, and rubber by 85 trees ha ${ }^{-1}$. Damar and pine forests at the study site had a relatively high density of trees, while the vegetation density in the rubber plantations was low. Samingan (1997) suggested that the estimated normal density of trees in production forest was 250 trees ha ${ }^{-1}$.

The results of vegetation analysis below showed that there were 29 species of plants that lived naturally in the wild under the damar stands (Figure 7). Asmayannur et al. (2012) argued that the undergrowth was important component in forest ecosystems to be reckoned the role. Medicinal plants and ornamental plants existed in MHSNP region can be developed in the buffer zone as sources of income for communities around the forest. The IVI calculation showed that the most dominant species under damar stand were coffee saplings with IVI of $46.2 \%$ then followed by Eleusine indica L. with IVI of $24.5 \%$, Panicum montanum with IVI of $21.1 \%$ and Pteridophyta with IVI of $13.5 \%$ (Table 3 ). Medicinal plants that grow in the damar understory that were, Commelina benghalensis L. was used as an ulcer drug with IVI of $1.9 \%$, Selaginella sp. as pulmonary drug with IVI of $7.9 \%$, and 4 types of plants as wound medicines consisting of: Clidemia hirta L. with IVI of 16.5\%, Melastoma sp. with IVI of $3.5 \%$, Melastoma affine with IVI of $9.9 \%$, and Eupatorium inulifolium with IVI of $1.6 \%$. Those species were often used by people around the forest as traditional medicines.

There were 23 species of plants that grow naturally under pine stands. Lower plant species that had the highest IVI were M.affine with IVI of $37.5 \%$, followed by Dicranopteris dichotoma with IVI of $24.2 \%$, Pteridophyta with IVI of

Table 2 Important value index of vegetation on damar, pine, and rubber in the MHSNP area

\begin{tabular}{|c|c|c|c|c|c|c|}
\hline & Type of plant & $\begin{array}{c}\mathrm{K} \\
\text { (individuals ha }^{-1} \text { ) }\end{array}$ & $\mathrm{RD}(\%)$ & DR (\%) & $\mathrm{RF}(\%)$ & $\begin{array}{l}\text { IVI } \\
(\%)\end{array}$ \\
\hline \multicolumn{7}{|c|}{ Damar in the Cipeuteuy Village } \\
\hline \multirow[t]{2}{*}{ Tree level } & Damar & 452.1 & 97.7 & 98.4 & 80.0 & 276.2 \\
\hline & Campedak & 10.4 & 2.3 & 1.6 & 20.0 & 23.9 \\
\hline \multirow[t]{2}{*}{ Pole level } & Damar & 100.0 & 92.3 & 94.8 & 85.7 & 272.8 \\
\hline & Coffee & 8.3 & 7.7 & 5.2 & 14.3 & 27.2 \\
\hline Sapling level & Coffee & 33.3 & 100.0 & & 100.0 & 200.0 \\
\hline \multicolumn{7}{|c|}{ Pine in the Tamansari Village } \\
\hline Tree level & Pine & 552.1 & 100.0 & 100.0 & 100.0 & 300.0 \\
\hline Pole level & Pine & 33.3 & 100.0 & 100.0 & 100.0 & 300.0 \\
\hline Sapling level & & & - & - & - & - \\
\hline \multicolumn{7}{|c|}{ Rubber in the Pangradin Village } \\
\hline \multirow[t]{2}{*}{ Tree level } & Rubber & 85.0 & 85.0 & 57.4 & 75.0 & 217.4 \\
\hline & Pine & 15.0 & 15.0 & 42.6 & 25.0 & 82.6 \\
\hline \multirow[t]{3}{*}{ Pole level } & Rubber & 660.0 & 94.3 & 92.9 & 71.4 & 258.7 \\
\hline & Durian & 20.0 & 2.9 & 4.3 & 14.3 & 21.5 \\
\hline & Mangosteen & 20.0 & 2.9 & 2.8 & 14.3 & 19.9 \\
\hline Sapling level & Rubber & 1040.0 & 100.0 & & 100.0 & 200.0 \\
\hline
\end{tabular}

$\mathrm{K}=$ Density; $\mathrm{RD}=$ Relative density; $\mathrm{DR}=$ Relative dominance; $\mathrm{RF}=$ Relative frequency; IVI = Importance Value Index

Table 3 Vegetation type understory of damar, pine, and rubber stands in the HSNP region

\begin{tabular}{|c|c|c|c|c|}
\hline Species & $\mathrm{K}$ (individuals $\mathrm{ha}^{-1}$ ) & $\mathrm{RD}(\%)$ & RF (\%) & IVI $(\%)$ \\
\hline \multicolumn{5}{|c|}{ Vegetation type understory of damar } \\
\hline Coffea arabica & 58,75 & 28.3 & 17.9 & 46.2 \\
\hline Eleusine indica & 44,37 & 21.4 & 1.5 & 24.5 \\
\hline Panicum montanum & 40,62 & 19.6 & 1.5 & 21.1 \\
\hline Pteridophyta & 6,250 & 3.0 & 10.5 & 13.5 \\
\hline \multicolumn{5}{|c|}{ Vegetation type understory of pine } \\
\hline Melastoma affine & 20000 & 19.6 & 17.9 & 37.5 \\
\hline Dicranopteris dichotoma & 12500 & 12.2 & 11.9 & 24.2 \\
\hline Pteridophyta & 9375 & 9.2 & 11.9 & 21.1 \\
\hline Andrographis paniculata & 16458 & 16.1 & 3.0 & 19.1 \\
\hline \multicolumn{5}{|c|}{ Vegetation type understory of rubber } \\
\hline Cynodon dactylon & 20000 & 34.5 & 13.3 & 47.8 \\
\hline Melastoma affine & 10500 & 18.1 & 16.7 & 38.9 \\
\hline Ligodium sp. & 4500 & 7.8 & 13.3 & 21.1 \\
\hline Eleusine indica & 4500 & 7.8 & 10.0 & 17.8 \\
\hline
\end{tabular}

$\mathrm{K}=$ Density; $\mathrm{RD}=$ Relative density; $\mathrm{RF}=$ Relative frequency; IVI = Importance Value Index 


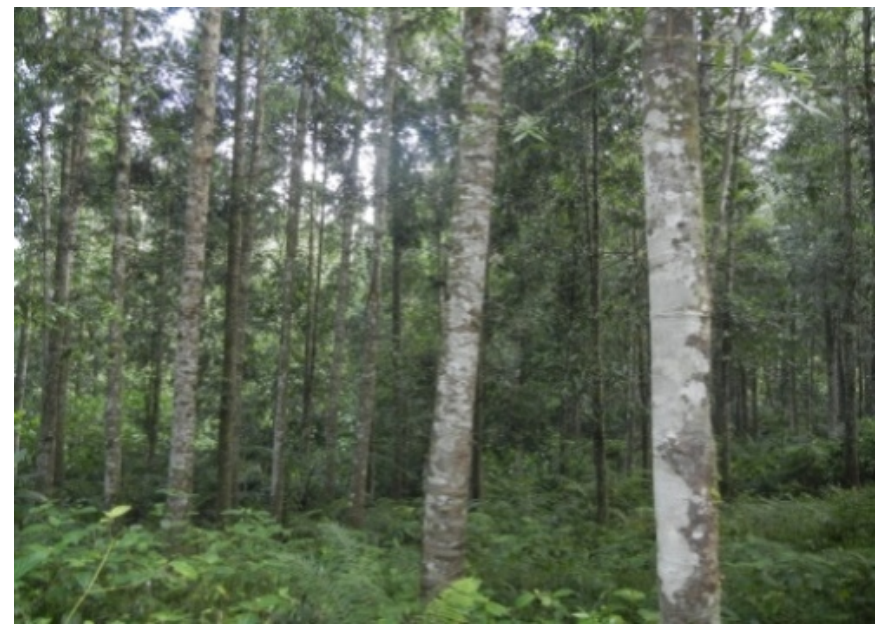

Figure 7 Agathis dammara stands in the Cipeuteuy Village in MHSNP area.

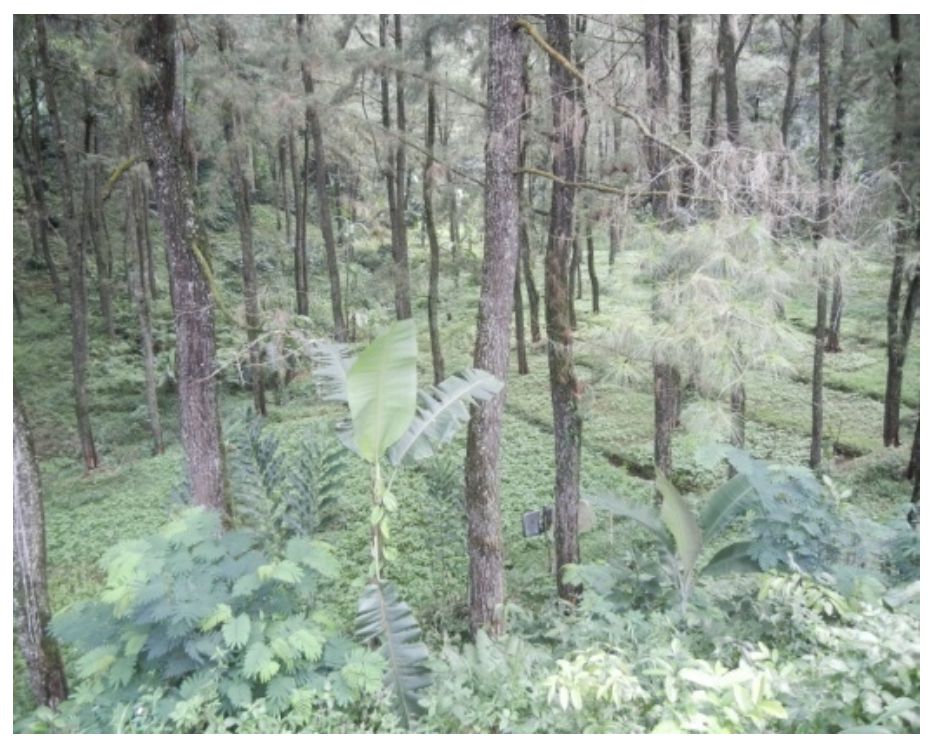

Figure 8 Pinus merkusii stands in the Tamansari Village in MHSNP area.

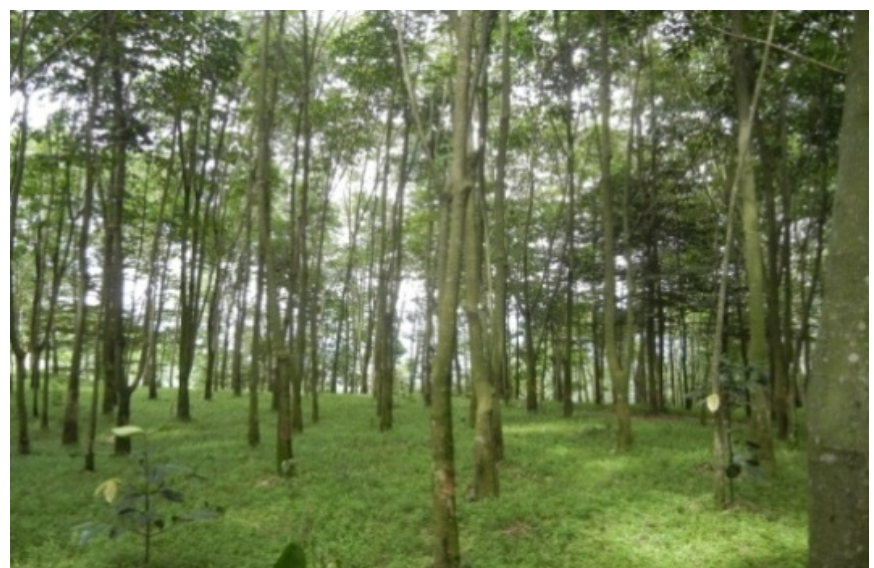

Figure 9 Rubber tree stands in the Pangradin Village in MHSNP area. 
21.1\%, and Andrographis paniculata with IVI of $19.1 \%$. (Table 3, Figure 8). This was consistent with Saharjo and Wardhana (2011) that found 23 species of vegetation in understory of pine stand in Forest Management Unit (FMU) Cianjur Perum Perhutani. Medicinal plant species and were often used by people around the forest as traditional drugs growing under pine stands, such as $D$. dichotoma plants as urinary tract infection medicine and cough medicine, Andrographis paniculata as fever medicine and diabetes, Alsophila glauca as diarrhea medicine with IVI of $3.1 \%$, Selaginella sp. as eczema drug with IVI of $6.7 \%$, Cinnamomum burmannii as thrush medication with IVI of $1.7 \%$, Schefflera sp. as arthritis medication with IVI of $1.7 \%$, Physalis sp. as ulcer medication with IVI of $7.6 \%$, and $M$. affine as diarrhea and thrush medication.

Rubber stand that grew in the area of MHSNP were communities planting prior to the expansion of the region into MHSNP (Figure 9). At the first, the area was pine forest that were managed by Perum Perhutani. The results of understory vegetation analysis showed that there were 13 species of plants that grow naturally under the rubber stands. This was in contrast with the results of Aththorick (2005) who found 21 species of understory vegetation in the Labuan Batu rubber plantation. The most dominant understory species in the study site were Cynodon dactylon with IVI of $47.8 \%$, followed by M. affine with IVI of $38.9 \%$, Ligodium sp. with IVI of $21.1 \%$, and Eleusine indica with IVI of $17,8 \%$ (Table 3 ). There were 5 types of medicinal plants in the rubber understory that were often used by people around the forest as traditional medicines, namely, M.affine as thrush medication, Eleusine indica as diarrhea medicine, Alsophila glauca as diarrhea medicine also with IVI of $8,4 \%$, Jatropha curcas as worming drug with IVI of $6,8 \%$ and Alpinia galanga as tinea versicolor drug with IVI of $5,1 \%$.

Index diversity of undergrowth beneath the damar stands with $\mathrm{H}^{\prime}$ value of 2.24, below the pine stands with $\mathrm{H}^{\prime}$ value of 2.16 and below rubber stands with value $\mathrm{H}^{\prime} 2.10$. Value diversity among the sites was low. According to Samingan (1997), the value of diversity was very high if it has H' value above 3.40. Low species diversity index showed that the types which found were not so many and only found the same types on each stand (Asmayannur \& Sham 2012).

Condition of stands is important to be known to assess the success of the planting crops. These conditions were reflected by several parameters, such as, the number of stems per ha, diameter, and plant height (Rusdiana \& Amalia 2012). The average height of the damar tree, pine, and rubber in the area of MHSNP were 20.3, 25.2, and $10.6 \mathrm{~m}$. The average diameter of damar tree, pine, and rubber in the area of MHSNP were 27.2, 30.7, and $11.1 \mathrm{~cm}$. Rusdiana and Amalia (2012) in FMU Banyumas showed that age increasing of pine plant, hence increasing plant height and diameter. Eighteen years old pine stand in FMU Banyumas has a height of $18.1 \mathrm{~m}$ and a diameter of $24.2 \mathrm{~cm}$, where as 22 years old pine stand has a height of $24.6 \mathrm{~m}$ and a diameter of $32.8 \mathrm{~cm}$. Pine plants diameter in the study site at the age of 25 years old was lower when compared with pine plants in FMU Banyumas. Rusdiana and Amalia (2012) suggested that pine plant growth was influenced by the characteristics of the soil, temperature, rainfall, and altitude.

\section{Conclusion}

Damar and pine forest conditions in the HSMNP region are still good with high levels of tree density, but has low species diversity. Pine (P. merkussi), rubber (H. brasiliansis) and damar (A. dammara) that existed in the HSMNP role not only in ecological aspects, but also in the economic and socio aspects. From the ecological aspects of forest ecosystems, they have the function and role in supporting the sustainability of the ecosystem. From the economic aspects, they can be one source of income for forest communities. From the socio aspects, people are involved in the utilization of forest resources. Damar sap and pine collection program in utilization zone area of MHSNP through community empowerment by applying the principles of sustainability and forest functions observance. Income contribution from rubber tapping higher than damar sap and pine to the total household income of farmers. The harvesting of pine sap, rubber and damar in the HSMNP can improve the local economy around the forest.

\section{References}

Ahenkan A, Boon E. 2011. Non-timber forest product (NTFPs): clearing the confusion in semantics. Journal of Human Ecology 33(1):1-9.

Asmayannur I, Chairul, Syam Z. 2012. The analysis of understory vegetation on jati emas (Tectona grandis L.) and jati putih (Gmelina arborea Roxb.) stand in Andalas University Campus. Jurnal Biologi Universitas Andalas 1(2):173-178.

Aththorick TA. 2005. Kemiripan komunitas tumbuhan bawah pada beberapa tipe ekosistem perkebunan di Kabupaten Labuhan Batu. Jurnal Komunikasi Penelitian 17(5):42-48.

Birgantoro BA, Nurrochmat DR. 2007. Forest resource utilization by people in KPH Banyuwangi Utara. Jurnal Manajemen Hutan Tropika 13(3):172-181.

Cahyono SA, Haryanti N, Jariyah NA, Indrajaya Y. 2006. Socio economic characteristics affecting household income of pine gum taper case study in Somagede, Kebumen, and Central Java. Jurnal Penelitian Sosial Ekonomi Kehutanan 3(2):109-116.

Cahyono SA. 2011. Factors that influences famers to tap pine in KHDTK Gombong. Tekno Hutan Tanaman 4(2):49-56.

Darusman D. 2000. Dimensi Kemasyarakatan dalam Pengelolaan Hutan. Bogor: Laboratorium Poleksos Fahutan IPB.

Dunggio I, Gunawan H. 2009. An overview on the history of national park management policy in Indonesia. Jurnal Analisis Kebijakan Kehutanan 6(1):43-56. 
Hastuti D, Marsono D, Irham, Sumardi. 2011. Classification ecosystem of the Gunung Merbabu National Park based on biological and socioeconomic aspects. Jurnal Manusia dan Lingkungan 18(2):85-97.

Irawan WSB, Suhendang E, Matangaran JR. 2007. Prediction model for copal production. Jurnal Manajemen Hutan Tropika 13(3):166-171.

Jacobson MG, Shiba PK. 2012. NTFP income contribution to household economy and related socio-economic factors: lessons from Bangladesh. Forest Policy and Economics 14:136-142. http://dx.doi.org/10.1016/j.forpol.2011. 08.003 .

JICA. 2007. Rencana Pengelolaan Taman Nasional Gunung Halimun Salak Periode 2007-2026. Bogor: JICA.

Junaedi E, Maryani R. 2013. Effect of spatial dynamics of socio-economic in the watershed landscape toward the existence of the forest landscape: Case studies on Citanduy Hulu Watershed and Ciseel Watershed, West Java. Jurnal Penelitian Sosial Ekonomi Kehutanan 10(2):122-139.

Maryudi A. 2012. Proverty alleviation efforts through a community forestry program in Java, Indonesia. Journal of Sustainable Development 5(2):43-53. http://dx.doi. org/10.5539/jsd. v5n2p43-53.

Rahmawati R et al. 2008. Pengetahuan lokal masyarakat Adat Kasepuhan: adaptasi, konflik dan dinamika sosioekologis. Jurnal Transdisiplin Sosiologi, Komunikasi, dan Ekologi Manusia 2(2):151-190.

Rusdiana O, Amalia RF. 2012. Land suitability of Pinus merkusii Jungh et de Vriese on ex-standing area of Tectona grandis Linn. F. Jurnal Silvikultur Tropika 3(3):174-181.

Saharjo BH, Wardhana HFP. 2011. The estimation of carbon stock potential on merkus pine (Pinus merkusii Jungh. et de Vriese in KPH Cianjur, Perum Perhutani III West Java and Banten. Jurnal Silvikultur Tropika 3(1):96-100.

Samingan T. 1997. Kondisi Ideal Aspek Vegetasi Suatu Kawasan Pelestarian Plasma Nutfah di Hutan Produksi. Bogor: Ecology Laboratory Faculty of Mathematics and Natural Science, Bogor Agricultural University.

Sannia B, Ismono H, Viantimala B. 2013. Related the rubber quality to income additional farmers village in program and non-program. Jurnal Ilmu Ilmu Agribisnis 1(1):3642 .

Schimdt FH, Ferguson JHA. 1951. Rain fall type based on wet and dry period ratios for Indonesia with Western New Guinea. Verh. No. 42. Jakarta: Direktorat Metereologi dan Geofisika .

Soegianto A. 1994. Ekologi Kuantitatif: Metode Analisis Populasi dan Komunitas. Jakarta: Penerbit Usaha Nasional.

Soerianegara I, Indrawan A. 2002. Ekologi Hutan Indonesia. Bogor: Faculty of Forestry, Bogor Agricultural University.

Sukadaryati, Dulsalam. 2013. The techniques of tapping pine to enhance its gum production using biostimulant agents. Jurnal Penelitian Hasil Hutan 31(3): 221-227.

Sunaryo, Uji T, Tuhurua EF. 2012. Jenis tumbuhan asing invasif yang mengancam ekosistem di Taman Nasional Gunung Gede Pangrango, Resort Bodogol, Jawa Barat. Berkala Penelitian Hayati17(2):147-152.

van Wilgen BW, Richardson DM. 2012. Three centuries of managing introduced conifers in South Africa: benefits, impact, changing perception and conflict resolution. Journal of Environmental Management 106:56-68. http://dx.doi.org/10.1016/j.jenvman.2012.03.052.

Village of Cipeuteuy. 2011. Village Cipeuteuy Monograph. Sukabumi: Village of Cipeuteuy.

Village of Pangradin. 2011. Village Pangradin Monograph. Bogor: Village of Pangradin.

Village of Tamansari. 2011. Village Tamansari Monograph. Bogor: Village of Tamansari.

Wijayanto N. 2002. Contribution of repong damar to regional economic and income distribution. Jurnal Manajemen Hutan Tropika 8(2):1-9.

Wulansari M, Aid A, Wilda K. 2012. Analisis pendapatan petani karet Sub UPP (Unit Pelaksana Proyek) Rantau di Kecamatan Hutungan Kabupaten Tapin. Jurnal Agribisnis Pedesaan 2(3):205-213.

Yatap H. 2008. The influence of socio-economic variables on landuse and landcover change in Gunung Halimun Salak National Park [thesis]. Bogor: Bogor Agricultural University. 